\title{
KNOWLEDGE MANAGEMENT TECHNOLOGY USING SECI AND WIL TO IMPROVE PERFORMANCE OF IN- FORMATION TECHNOLOGY DIVISION IN PANGESTU JAYA LTD.
}

\author{
Joang Ipmawati ${ }^{1 *}$, Yana Hendriana ${ }^{2}$ \\ 1,2 Universitas Nahdlatul Ulama Yogyakarta \\ * Corresponding author E-mail: joang@unu-jogja.ac.id
}

\begin{abstract}
Keywords:
Knowledge Management; Technology;

Design; SECI; WIL.
\end{abstract}

\begin{abstract}
Information Technology Division is one of the divisions in Pangestu Jaya Ltd. which engaged in IT Department, where in this division there are several sub-divisions that are interrelated and have the duty and responsibility of each indi-vidual to improve services in The company. Turnover is one of the major obstacles in order to still be able to keep the knowledge technology in the company, because there are still many employees with outsourced status who often do turnover in IT division, so difficult to keep the knowledge. therefor need a knowledge manage-ment technology which is capable of storing, distributing knowledge in order to renew even while maintaining corporate knowledge. The system design of this research used SECI and WIL (Work Integrated Learning).
\end{abstract}

\section{Introduction}

Information Technology is one of the factors supporting or capital to improve the business processes of an enterprise. The development of information technology offers an effect to any activities in the company. With the information technology that is able to convert any data into useful information for the company. The knowledge in the company is the major capital, or assets essential for companies to be able to compete. With the knowledge management, the company can progress and create the quality of human assets within the company. build up whether the SECI model was more broadly acknowledged than other KM models; examine particular statistic subtle elements of inquire about considers on the SECI model; explore the weaknesses of the show in practice; and create a digest of the utilize of the model in regard of the period we surveyed [1]. According to Drucker is quoted in the book [2] knowledge is information or change a person, it happens when the information becomes the basis for action, or when the information empower a individual or institution to require activities diverse or more compelling activity from the past activity. While knowledge management system is a mechanism and a process that is integrated into the storage, maintenance, organizing business information [3].

IT Division which is one of the department in Pangestu Jaya Ltd. engaged in the IT department, which in this division there are several sub-divisions that are interrelated and have the duties and responsibilities to improve services. Turnover is a matter that cannot be avoided by the company, thus becoming a major obstacle, to keep the existing knowledge along with the turnover of employees in the company, this is also due to the status of the employees are still outsourced frequent turnover that led to a loss of knowledge on IT division, so difficult to keep even retain the knowledge [4]. Therefore, the need for a system capable of storing, distributing and even update the knowledge in order to keep corporate knowledge as an asset to improve the performance of human resources within the company [5]. Within the area of innovation and technology management education, the area of work-integrated learning (WIL) through industry placements has received increased attention in developing innovation skills through the uncertain and unstructured nature of real-world entrepreneurial environments [6].

The reason of this study is as takes after:

- Perform an investigation of the information administration prepare that has been running on the company.

- Planning a knowledge management framework which can be utilized as a medium for sharing it documented. 


\section{Literature Review}

Knowledge is the application of information believed to be directly used to make decisions in the act [7]. Knowledge that consists of data and information, then organized and processed to convey understanding, experience, learning and skills applicable to today's business problems [8]. It can be concluded that the knowledge comprises of information and data utilized to create decisions [9]. Knowledge Management is the organization's exercises in overseeing knowledge as a resource, the conveyance of effort required appropriate knowledge to the proper people and in a brief time, so they can be connected with each other, share knowledge and apply it in their day by day work to make strides organizational performance [10]. Knowledge Management is considering coordination efficiently from individual organizations, innovations, processes and organizational structures in arrange to include esteem through reuse and development [11]. Knowledge Management is a process of identifying, selecting and arranging organizations typically are not structured in the organization. Knowledge Management can encourage learning in the organization that can lead to the creation of further knowledge [12] [13]. It can be concluded that knowledge management could be a handle for managing organizational knowledge as a resource to include value through reuse and development [14].

The reason of knowledge management according [15] as follows:

- To encourage the smooth exchange of knowledge..

- Reduce the corporate memory loss because of depreciation of employees and retired employees.

- Identify assets and basic knowledge ranges so that the company "Knowing what you wish to know and a great thing and why

- Construct a toolkit of methods that can be utilized independently in groups, and in organizations to stem the potential misfortune of mental capital.

Work-Integrated Learning (WIL) is characterized as "a organized methodology for joining classroom considers with learning through beneficial Works encounters in a field related to a staff or career goals" [16]. There are two primary characteristics of WIL. First, it must include association between the staff, instructive institution and boss, with indicated duties for each party [17]. Second, it must moreover include reflection on learning from the encounter [18]. Despite these two common characteristics, there are different shapes of WIL [19]. The First frame is agreeable instruction, characterised by a legally binding course of action between the college and firm which diagrams the compensation and work conditions, includes the contracting of staff, substitutes staff between the firm and college and requires fulltime staff to help with their needs all through the program [20]. The second frame of WIL is work-based learning (WBL) which offers adaptability both in the passage and exit from the program as well as scope and sort of evaluation, which postures issues in degree completion and integration between learning within the work environment and the educational programs [21]. The third frame of WIL is the work environment learning program (WPL) [22], which is based on the delivery of the course within the work environment [23]. Typically as a rule focused on senior and center supervisors. Whereas it has the preferences of expanding staff enrollment through coming to a proficient advertise as well as being a source of unused course fabric and investigate openings, it is costly to manage because it requires extra staff travel and data and Communications innovation (ICT) administrations [20]. The fourth sort of WIL is Community benefit performed through the staff setting. This incorporates 'monitored Benefit experiences' but may be seen as a frame of cheap work and unacceptable in an Industry setting [24]. The fifth sort of WIL is the situation that includes a closely observed work involvement whereby the staff has deliberateness learning objectives and reflects effectively on them. This gives staff with openings for proficient advancement and profitable work put introduction [24] [25]. The directory is characterized as a board in an organization or expansive company posting names and areas of offices, people and others [26].

Business partners refer to the supervisors inside businesses and business visionaries in those firms locked in in UBC [27]. These businesses may have staff for WIL situations. Government partners incorporate both government and state governments that will give subsidizing for UBC, promote it inside the industry conjointly offer WIL situations, for the occasion at different guard, natural, water, transport and science-based open organizations. In spite of the fact that not continuously said due to their less coordinated part, mediators make up the ultimate key partner bunch, which can impact university-business trade [28]. Mediators are commonly alluded to as innovation interpreters [29], brokers [30], bridgers [31]; [32], information mediators [33], and superstructure associations [15]. In expansion to progressing connectedness and bridging ties inside the advancement framework, middle people may too 'create modern conceivable outcomes and dynamism inside the system' [34]. A few cases incorporate innovation exchange workplaces, hatcheries and science parks. In a WIL setting, [35], contend that communication can orange from arm's length where there's inadequate communication between the college and the firm to insert characterized by tall levels of communication. Furthermore, Kirtikara [36] found that dialect was a profoundly petulant issue in WIL Communications between firms and colleges as phrasing was befuddling and there was a small shared understanding.

Model-Driven Architecture (MDA) gives a demonstrate transformation system for transitioning between OOAD stages. Considering the focal points of MDA in stage moves, this ponder proposes that coordination customary OOAD instruction with the MDA system and portraying move relations in diagrammatic representations might move forward employee understanding of the moves [37].

\section{Method}

To do this early organize of research is conducted interviews with clients and make perceptions related straightforwardly to the company and through the literature to discover studies supporting hypotheses. After collecting the information the following step is to analyze the issues and needs [38]. After analyzing wants and issues that occur within the company, it'll create an arrangement that will be outlined, which is able to be outlined to require the plan of commerce forms that are running (current) and after that do a framework plan proposal. When the plan is completed it to the another arrange to advancement organize. When another improvement stage of making inductions and recommendations within the last stages of the investigation [39].

The study was based on a case think about of a WIL arrangement program at the Pangestu Jaya Ltd. including IT Division and engineering Division (26 engineering staff, the penultimate year of think about as well as eight data technologies and six business and technology Management Knowledge. last inquire about). The 20-week full-time situation was a central component focused on an inventive industry venture, for the occasion of the improvement or commercialization of modern innovation, item or benefit [38]. A case study approach was chosen because it gives the advantage of point-by-point capture of reality. With the knowledge management, the company can progress and create the quality of human assets within the company and build up whether the SECI model. 


\section{Results and Discussion}

IT Division is one of the divisions that are inside the company Pangestu Jaya Ltd. Division of IT may be a division beneath the IT Directorate. This division duties are to support the exercises and advancement of human resources in an organization which may be the appearance of the show socialization, externalization, combination, internalization (SECI), agreeing to Nonaka and Takeuchi utilized the existing information innovation in organizations through the four-way change [3].

Table 1 shown an application of the SECI model of the company in conducting information sharing.

Table 1: Knowledge Cycle Mapping

\begin{tabular}{|c|c|}
\hline \begin{tabular}{ll} 
& \multicolumn{1}{c}{ Socialization } \\
& (Tacit to Tacit) \\
$>\quad$ & External Meeting \\
$>$ & Internal Meeting \\
$>$ & Seminars \\
$>$ & Discussion (face to face)
\end{tabular} & 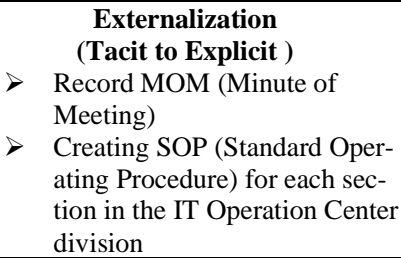 \\
\hline $\begin{array}{ll}\text { Internalization } \\
\\
\text { (Explicit to Tacit }) \\
>\quad \text { Read company product } \\
\text { Read MOM (Minute of } \\
\text { Meeting) }\end{array}$ & 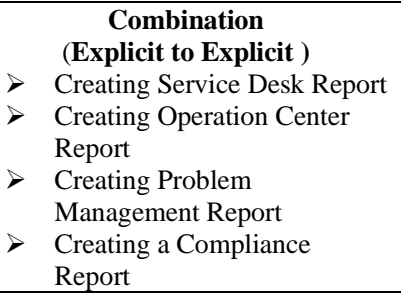 \\
\hline
\end{tabular}

Below is the scientific classification of knowledge that's contained in all parts of the IT Division. Where in each division includes knowledge that must be kept up so that any knowledge isn't misplaced.

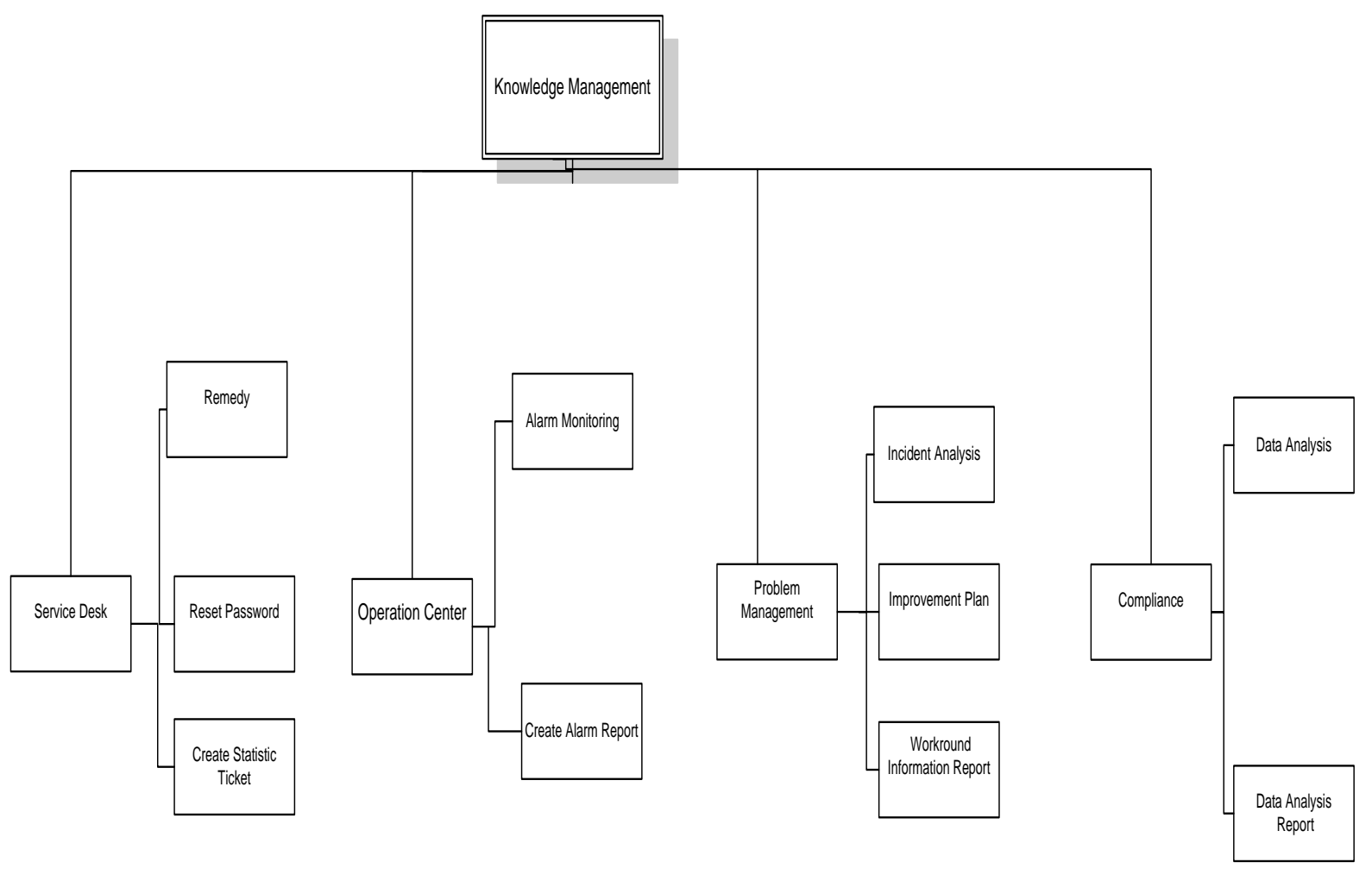

Fig. 1: Knowledge Taxonomy

Figure 1 appears Knowledge taxonomy explained below:

1. Service Desk

- Remedy could be an ask for Request for Assistance (RFA) through the web. A one of a kind number (INC Remedy Ticket Number) will be given for any ask that will be taken care of by the Service Desk. Service Desk will serve all demands for assistance / Request for Assistance (RFA) client related with the application of standard benefit and a premium benefit. For illustration: (a.) Standard Service Application: Single Mediation; (b.) Premium app: HRIS and MKIOS.

- Reset password. Benefit Desk has been given the authorization to reset the password for different applications either standard or premium contained within the company. password reset action conducted within 1 month.

- Create a Statistic Ticket Report. Insights ticket report contains increment and diminishes the number of tickets going on within the week. The report is data that can be utilized as a reference to the advancement for each week.

2. Operation Center 
- Alarm Monitoring. The responsibility is to screen the exercises of any conditions that happen in each item. The caution that appears will allow an activity to be taken by the worker when the framework blunder is happening.

- Create an Alarm Report. Result alert report may be a report containing the increase and decrease within the number of alerts in one week.

3. Problem Management

- Incident Analysis. An incident is an occasion where an item targets beneath the standards set by the company. So that the incident analysis is performed to discover the cause of the decrease targets that have occurred.

- Improvement plan. The arrangement for each incident.

- Incident report. Depicts an occurrence that comprises of an issue, root-cause, analysis and arrangement of the incident that occurred.

4. Compliance

- Data Analysis. Analyzing the information reduction in the victory rate, transaction, non-success rate and mistake for every product.

- Data Analysis Report. To form a report on the information that needs to be created from each transaction made all the item portion of IT division4. Compliance

- Data Analysis. Analyzing the information reduction in the victory rate, transaction, non-success rate and mistake for every product.

- Data Analysis Report. To form a report on the information that needs to be created from each transaction made all the item portion of IT division.

Table 2 shown the current knowledge management issues in Pangestu Jaya Ltd.

Table 2: The Current Issues

\begin{tabular}{|l|l|}
\hline SECI Model & $\begin{array}{l}\text { The issues contained in the SECI model company before the development of knowledge management, as } \\
\text { follows: } \\
1 . \quad \text { Externalization }\end{array}$ \\
Before the improvement of KM to record the MOM still utilize paper so most likely still common mis- \\
fortune of the MOM record. MOM that has been recorded is at that point dispersed through email to all \\
meeting members. One of the impediments in distributing MOM that's the restricted capacity of the \\
email that's preventing the method of distributing MOM. \\
Creating SOP \\
$\begin{array}{l}\text { Still less imbalance of the distribution of the whole SOP on each worker. } \\
\text { 2. Combination } \\
\text { Make a report for each division. Need of knowledge had by representatives in analyzing an activity for } \\
\text { each portion of the IT Operations Center division. } \\
\text { 3. Internalization } \\
\text { Read MOM } \\
\text { These days each employee got the MOM through email. There are restrictions to the capacity } \\
\text { of the email, cause uneven dispersion so that not all employees are mindful of the substance } \\
\text { and the visit misfortune of the MOM since employees can remove it purposefully or not. }\end{array}$ \\
\end{tabular}

Table 2 appears The proposed framework design will clarify the SECI model that will be proposed and OOAD (Object Oriented Analysis and Design with the Unified Process) as the instruments utilized to design the framework.

Below are all activities as well as the proposed highlights that knowledge must be kept up are as follows:

Table 3: Activity Mapping

\begin{tabular}{|c|c|c|}
\hline Department & Activities & $\begin{array}{r}\text { Proposed Feature } \\
\end{array}$ \\
\hline \multirow[t]{2}{*}{$\begin{array}{l}\text { Service Center / Oper- } \\
\text { ation Center/ Problem } \\
\text { Management / } \\
\text { Compliance }\end{array}$} & Create Remedy & $\begin{array}{l}\text { The proposed features that can be used to } \\
\text { keep the knowledge within the action of } \\
\text { making a remedy that is: } \\
\text { - News feature } \\
\text { To be able to conduct a discourse on how } \\
\text { to remedy issue solving occurs. } \\
\text { - File feature } \\
\text { Files feature could be an include that } \\
\text { can be utilized to upload and download } \\
\text { files that are utilized to make and give } \\
\text { arrangements to remedy. }\end{array}$ \\
\hline & Create Report & $\begin{array}{l}\text { The proposed features can be utilized to keep } \\
\text { the knowledge, to create a report on the } \\
\text { movement of the feature record and it can be } \\
\text { utilized to transfer and download layouts and } \\
\text { collection reports. }\end{array}$ \\
\hline
\end{tabular}


Here's a table knowledge cycle mapping for Pangestu Jaya Ltd

Table 4: Knowledge Cycle Mapping

\begin{tabular}{|l|ll|}
\hline \multicolumn{1}{|c|}{ Knowledge Cycle } & \multicolumn{1}{c|}{ Propose Features } \\
\hline $\begin{array}{l}\text { Knowledge Creation and } \\
\text { Capture Phase }\end{array}$ & $>$ & MOM (Minute of Meeting) \\
\hline $\begin{array}{l}\text { Knowledge Sharing and } \\
\text { Dissemination Phase }\end{array}$ & $>$ News (Discussion Forum) \\
& $>$ Download File \\
\hline $\begin{array}{l}\text { Knowledge Acquisiton and } \\
\text { Aplication Phase }\end{array}$ & $>$ Profile User \\
\hline
\end{tabular}

Here's a table the new mapping for SECI Model for Pangestu Jaya Ltd

Table 5: The New SECI Model

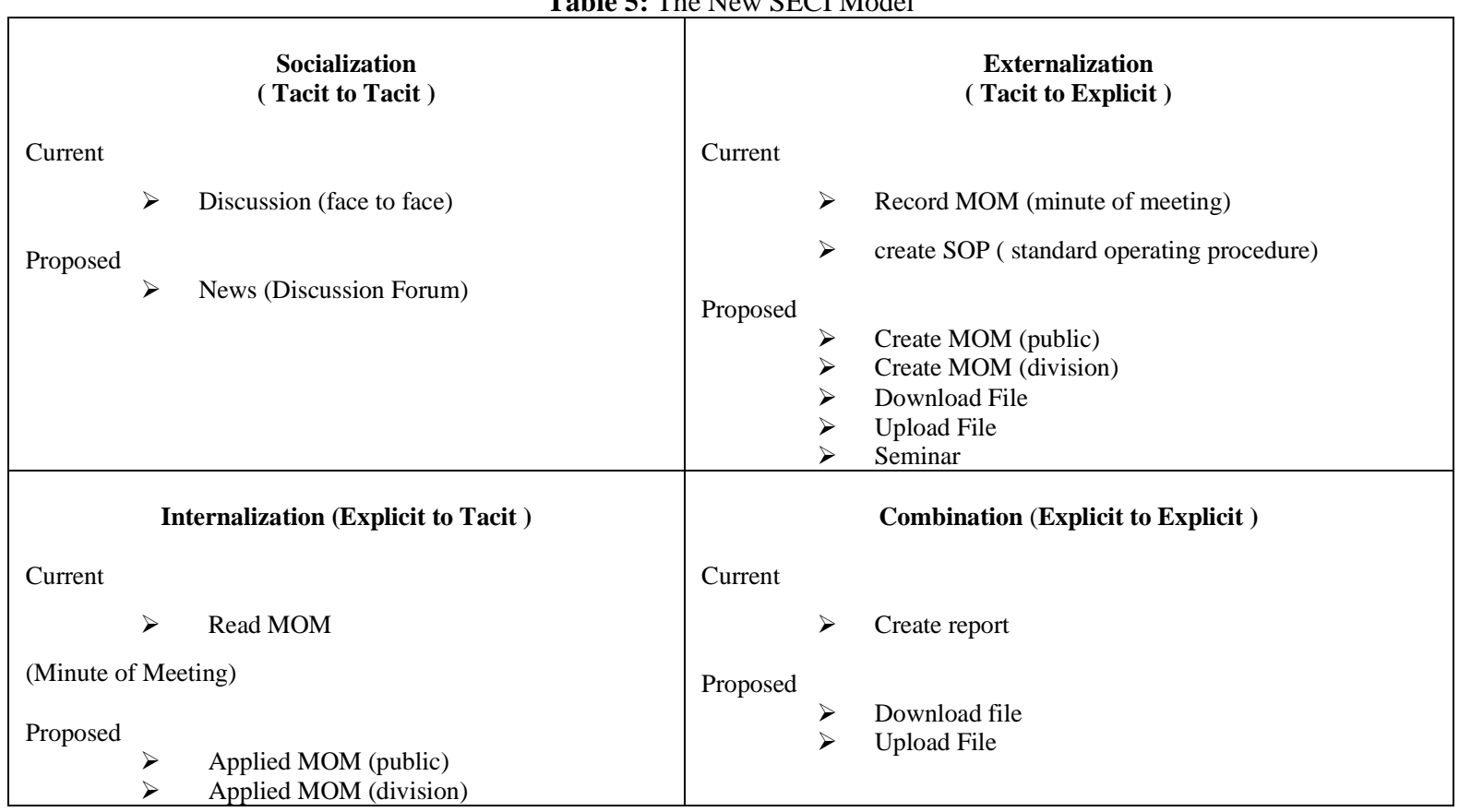

Here's a Use Case Diagram of the framework to be built. Within the Use Case diagram underneath depicts the interactions made by each on-screen character of the framework.

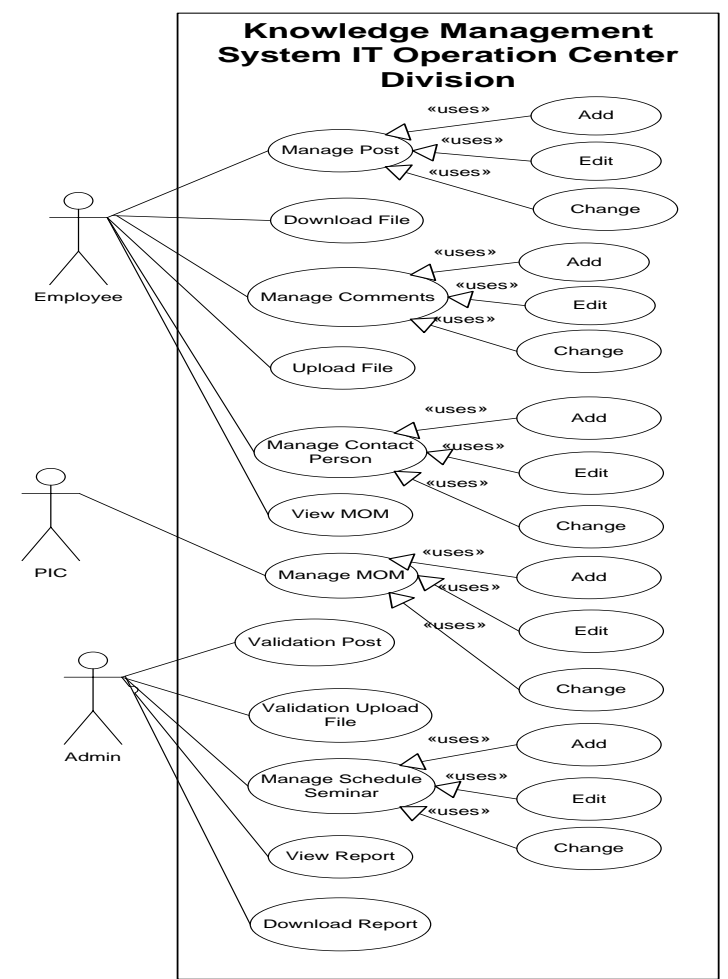

Fig. 2: Use case Diagram for Knowledge Management Pangestu Jaya Ltd. 
Figure 2 shows use case diagram that used in the development knowledge Technology for IT Division which is one of the department in Pangestu Jaya Ltd. engaged in the IT department, which in this division there are several sub-divisions that are interrelated and have the duties and responsibilities to improve services.

Here's a Domain Class Diagrams are used to describe the classes that are needed.

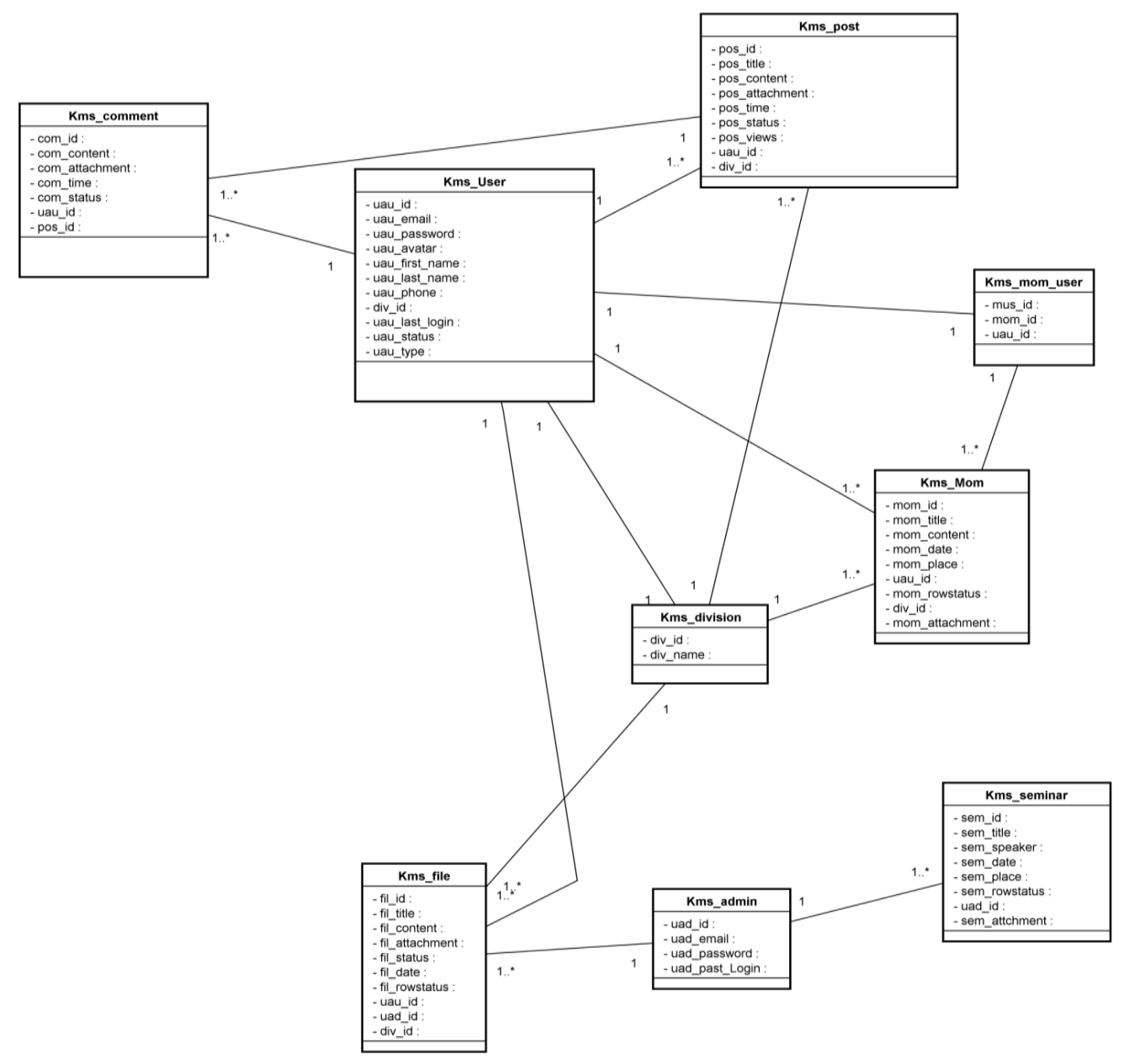

Fig. 3: Domain Class Diagram

Figure 3 shows the Domain Class Diagram which has been modeled in the design of network architecture Below Figure 4 shows the design of network architecture for knowledge management framework on the IT division. Where within the picture below there's a PC utilized as a server which is connected through a LAN arrange for all workers to be able to get to the Knowledge Management Framework.

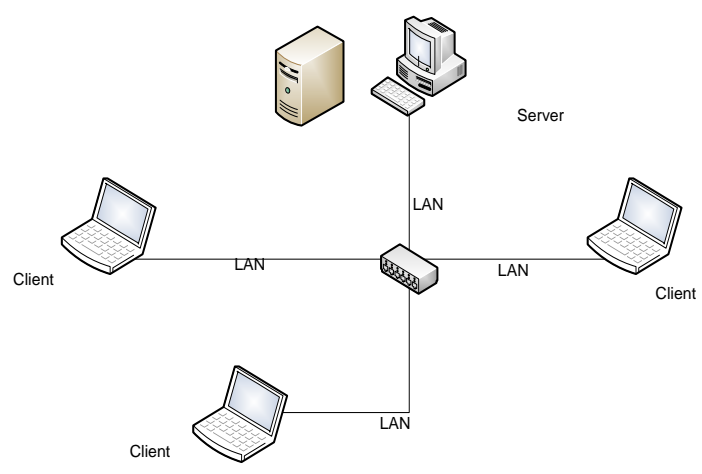

Fig. 4: Network Architecture

Building on the mapping by Abuaddous [40] by technologies exchanged, organizational type and measure, this mapping is expanded to analyse the results of the collaboration counting commercialization of new items and services, joint research driving to publications, research respects ventures, research wage and international research collaboration, enrollment of talented staff and purposeful to renew WIL interest. 


\section{Conclusion}

In this study, for the primary time is collecting data from Pangestu Jaya Ltd. particularly from IT Division. Data collection strate-gies utilized conducting interviews and observations specifically to the company. This study used the SECI model of analysis and design OOAD (Object Oriented Analysis and Design with the Unified Process) [41]. The framework design moreover covers the design of the database utilized to depict each table is required within the design. Essentially Knowledge management frameworks can be used as a medium for sharing knowledge for each employee.

And for the longer-term development of the knowledge administration framework, we provide recommendations to including a mobile platform application. So it can perform discourse at dialog forums anywhere and anytime, so that knowledge sharing isn't restricted by space and time. Despite its important suggestions, the study does have impediments and clears the way for future re-search. First, it included a single case study of Pangestu Jaya Ltd. and in this way for future research in other companies can incre-ment the generalisability of results. On occasion, commerce companies have an expanding intrigued in WIL in boosting the rele-vance of their programs and the employability of their staff [24]. Second, a quantitative study can be utilized to advance and test the conceptual system proposed in this research. The quantitative results may be utilized to assess the significance of different parts and can offer assistance educate the improvement of staffing profiles and work details such as administrator, administrative staff, placement coordinators.

\section{Acknowledgement}

This research was supported by grant Pangestu Jaya Ltd.

Special thanks to our students (Hamdan Irfan Wijaya, Wahma Ravenna Rafail) in Universitas Nahdlatul Ulama Yogyakarta for their support in this research

\section{References}

[1] A. O. Adesina and D. Ocholla, "The SECI Model in Knowledge Management Practices: Past, Present and Future," Mousaion South African J. Inf. Stud., vol. 37, no. 3, pp. 1-34, 2019.

[2] H. Andreas L. Tobing S.I.P and I. B. Benyamino L. Tobing M.M, "BEHAVIORAL INTENTION TO THE USE OF FINTECH AND GOVERNMENT SUPPORT IN DEVELOPING THE THEORY OF TECHNOLOGY ACCEPTANCE MODEL,” Int. J. Adv. Res., vol. 08, no. 04, pp. 395-400, 2020, doi: 10.21474/ijar01/10790.

[3] M. L. Farnese, B. Barbieri, A. Chirumbolo, and G. Patriotta, "Managing knowledge in organizations: A nonaka's SECI model operationalization," Front. Psychol., vol. 10, 2019, doi: 10.3389/fpsyg.2019.02730.

[4] N. P. Melville, "Information systems innovation for environmental sustainability," MIS Quarterly: Management Information Systems, vol. 34, no. 1 . pp. $1-21,2010$, doi: $10.2307 / 20721412$.

[5] C. S. Lee and R. S. Kelkar, "ICT and knowledge management: Perspectives from the SECI model," Electron. Libr., vol. 31, no. 2, pp. 226-243, 2013, doi: 10.1108/02640471311312401.

[6] D. F. Kuratko and S. Hoskinson, "Introduction: The challenges of corporate entrepreneurship in the disruptive age," Advances in the Study of Entrepreneurship, Innovation, and Economic Growth, vol. 28. pp. 1-9, 2018, doi: 10.1108/S1048-473620180000028011.

[7] T. Burström, V. Parida, T. Lahti, and J. Wincent, "AI-enabled business-model innovation and transformation in industrial ecosystems: A framework, model and outline for further research,” J. Bus. Res., vol. 127, pp. 85-95, 2021, doi: 10.1016/j.jbusres.2021.01.016.

[8] R. Kelly Rainer and C. G. Cegielsky, Introduction to Information System: Enabling and Transforming Business, vol. 91, no. 5. 2012.

[9] M. M. Malik, S. Abdallah, and M. Hussain, "Assessing supplier environmental performance: Applying Analytical Hierarchical Process in the United Arab Emirates healthcare chain," Renewable and Sustainable Energy Reviews, vol. 55. pp. 1313-1321, 2016, doi: 10.1016/j.rser.2015.05.004.

[10] H. Prabowo, "Knowledge Management di Perguruan Tinggi," Binus Bus. Rev., vol. 1, no. 2, p. 407, 2010, doi: 10.21512/bbr.v1i2.1087.

[11] D. G. Schniederjans, C. Curado, and M. Khalajhedayati, "Supply chain digitisation trends: An integration of knowledge management," Int. J. Prod. Econ., vol. 220, 2020, doi: 10.1016/j.ijpe.2019.07.012.

[12] M. Evans, K. Dalkir, and C. Bidian, "A Holistic View of the Knowledge Life Cycle: The Knowledge Management Cycle (KMC) Model," Electron. J. Knowl. Manag., vol. 12, no. 2, pp. 85-97, 2014.

[13] A. M. Abubakar, H. Elrehail, M. A. Alatailat, and A. Elçi, "Knowledge management, decision-making style and organizational performance," J. Innov. Knowl., vol. 4, no. 2, pp. 104-114, 2019, doi: 10.1016/j.jik.2017.07.003.

[14] K. Dalkir, D. A. Bedford, and K. Miller, "Knowledge management in LIS education: Bridging research and practice," Proc. Assoc. Inf. Sci. Technol., vol. 52, no. 1, pp. 1-4, 2015, doi: 10.1002/pra2.2015.145052010015.

[15] K. Dalkir, "The Knowledge Management Cycle," in Knowledge Management in Theory and Practice, 2020, pp. $40-61$.

[16] R. Ajjawi, J. Tai, T. Le Huu Nghia, D. Boud, L. Johnson, and C. J. Patrick, “Aligning assessment with the needs of work-integrated learning: the challenges of authentic assessment in a complex context," Assess. Eval. High. Educ., vol. 45, no. 2, pp. 304-316, 2020, doi: $10.1080 / 02602938.2019 .1639613$.

[17] A. Karim, M. Campbell, and M. Hasan, "A new method of integrating project-based and work-integrated learning in postgraduate engineering study," Curric. J., vol. 31, no. 1, pp. 157-173, 2020, doi: 10.1080/09585176.2019.1659839.

[18] T. Judene Pretti, B. Etmanski, and A. Durston, "Remote work-integrated learning experiences: Student perceptions," Int. J. Work. Learn., vol. 21, no. 4, pp. 401-414, 2020.

[19] A. Venville, B. Lynch, and E. Santhanam, "A systematic approach to the evaluation of the student experience in work-integrated learning," Int J. Work. Learn., vol. 19, no. 1, pp. 13-21, 2018.

[20] T. Bowen, "Work-integrated learning placements and remote working: Experiential learning online," Int. J. Work. Learn., vol. 21, no. 4, pp. 377-386, 2020 .

[21] N. J. Dewasiri and G. D. Samarasinghe, "Book review: Nalin Abeysekera. Marketing Sinhalen,” Asia-Pacific J. Manag. Res. Innov., vol. 15, no. 3, pp. 122-124, 2019, doi: 10.1177/2319510x19873209.

[22] P. Chad, "Equitable work-integrated-learning: Using practical simulations in university marketing subjects," Australas. Mark. J., vol. 28, no. 2 , pp. 119-127, 2020, doi: 10.1016/j.ausmj.2020.01.004.

[23] M. W. . Maduranga and R. Abeysekera, "MACHINE LEARNING APPLICATIONS IN IOT BASED AGRICULTURE AND SMART FARMING: A REVIEW,” Int. J. Eng. Appl. Sci. Technol., vol. 04, no. 12, pp. 24-27, 2020, doi: 10.33564/ijeast.2020.v04i12.004.

[24] Y. A. Rivera-Arrubla, A. Zorio-Grima, and M. A. García-Benau, "The integrated reporting concept as an innovation in corporate reporting," $J$. Innov. Knowl., vol. 1, no. 3, pp. 144-155, 2016, doi: 10.1016/j.jik.2016.01.016.

[25] G. Reynolds and M. Grimley, "TEACHING FIRST LEVEL TERTIARY ACCOUNTING USING A GRAPHICAL METHOD TO IMPROVE STUDENTS' UNDERSTANDING AND ENGAGEMENT," PEOPLE Int. J. Soc. Sci., vol. 5, no. 2, pp. 103-122, 2019, doi: 10.20319/pijss.2019.52.103122 
[26] W. Pujiyono, Y. Hendriana, and I. D. Susanti, "Interactive learning media based on RPP ICT," 2017, doi: 10.1109/ICITSI.2016.7858218.

[27] D. S. Siegel, D. A. Waldman, L. E. Atwater, and A. N. Link, "Commercial knowledge transfers from universities to firms: Improving the effectiveness of university-industry collaboration," J. High Technol. Manag. Res., vol. 14, no. 1, pp. 111-133, 2003, doi: 10.1016/S1047$8310(03) 00007-5$.

[28] T. Abbate, F. Cesaroni, and A. Presenza, "Knowledge transfer from universities to low- and medium-technology industries: evidence from Italian winemakers," J. Technol. Transf., 2020, doi: 10.1007/s10961-020-09800-x.

[29] D. F. Kuratko and J. S. Hornsby, "Corporate Entrepreneurship and Middle Managers: A Model for Corporate Entrepreneurial Behavior," Acad. Manag. J., vol. 12, no. 5, pp. 87-119, 2011.

[30] A. B. Hargadon, "Firms as knowledge brokers: Lessons in pursuing continuous innovation," Calif. Manage. Rev., no. 3, pp. 209-227, 1998, doi: $10.2307 / 41165951$.

[31] J. Bessant and H. Rush, "Building bridges for innovation: the role of consultants in technology transfer," Res. Policy, vol. 24, no. 1, pp. 97-114, 1995, doi: 10.1016/0048-7333(93)00751-E.

[32] B. McEvily and A. Zaheer, "Bridging ties: A source of firm heterogeneity in competitive capabilities," Strateg. Manag. J., vol. 20, no. 12, pp. 1133-1156, 1999, doi: 10.1002/(SICI)1097-0266(199912)20:12<1133::AID-SMJ74>3.0.CO;2-7.

[33] A. Popp, “'Swamped in information but starved of data': Information and intermediaries in clothing supply chains," Supply Chain Manag., vol. 5, no. 3, pp. 151-161, 2000, doi: 10.1108/13598540010338910.

[34] R. K. Sachan et al., "Optimizing Basic COCOMO Model Using Simplified Genetic Algorithm," Procedia Comput. Sci., vol. 89, pp. 492-498, 2016, doi: 10.1016/j.procs.2016.06.107.

[35] M. Rangraz and L. Pareto, "Workplace work-integrated learning: supporting industry 4.0 transformation for small manufacturing plants by reskilling staff," Int. J. Lifelong Educ., 2021, doi: 10.1080/02601370.2020.1867249.

[36] E. Ruayruay, K. Kirtikara, M. Nopharatana, K. Chomsuwan, and S. Suwannathep, "Work-integrated learning competencies: A case study in a food engineering practice school program," Int. J. Instr., vol. 13, no. 2, pp. 707-720, 2020, doi: 10.29333/iji.2020.13248a.

[37] S. S. Shin, "Evaluation of model driven architecture-based instruction for understanding phase transitions in object-oriented analysis and design," ACM Trans. Comput. Educ., vol. 16, no. 4, 2016, doi: 10.1145/2914797.

[38] Y. Hendriana, A. Pranolo, S. Sulaiman, and L. H. Fong, "Generic shopping mall directory mobile application," in Proceedings - 2015 International Conference on Science in Information Technology: Big Data Spectrum for Future Information Economy, ICSITech 2015, 2016, pp. 363-368, doi: 10.1109/ICSITech.2015.7407833.

[39] M. Mukherjee, "Object-Oriented Analysis and Design,” Int. J. Adv. Eng. Manag., vol. 1, no. 1, p. 18, 2016, doi: 10.24999/ijoaem/01010003.

[40] H. Y. Abuaddous, A. A. M. Al Sokkar, and B. I. Abualodous, "The impact of knowledge management on organizational performance," Int. J. Adv. Comput. Sci. Appl., vol. 9, no. 4, pp. 204-208, 2018, doi: 10.14569/IJACSA.2018.090432.

[41] H. J. Choi, J. C. Ahn, S. H. Jung, and J. H. Kim, "Communities of practice and knowledge management systems: effects on knowledge management activities and innovation performance," Knowl. Manag. Res. Pract., vol. 18, no. 1, pp. 53-68, 2020, doi: 10.1080/14778238.2019.1598578 